\title{
Ecophysiology and dynamics of nitrogen removal bacteria in a sequencing batch reactor during wastewater treatment start-up
}

\author{
A. Ziembińska-Buczyńska ${ }^{1}$ (D) A. Banach-Wiśniewska ${ }^{1} \cdot$ M. Tomaszewski ${ }^{1} \cdot$ I. Poprawa ${ }^{2} \cdot$ S. Student ${ }^{3,4} \cdot$ G. Cema ${ }^{1}$
}

Received: 17 October 2018 / Revised: 3 February 2019 / Accepted: 13 February 2019 / Published online: 23 February 2019

(c) The Author(s) 2019

\begin{abstract}
Nitrogen removal communities performing wastewater treatment consist of ammonia oxidisers, nitrite oxidisers, denitrifiers, and anammox bacteria, and the proportion and activity of particular microbial groups depend not only on the physiochemical parameters of the bioreactor, but also on the composition of the inoculum. Nitrifiers and denitrifiers usually dominate in conventional wastewater treatment systems due to the fact that nitrification and denitrification are the most commonly used nitrogen removal processes. However, from the economical point of view in case of wastewater with high ammonia concentrations, anammox-based technologies are desirable for their treatment. The disadvantage of such systems is slow anammox bacteria growth, which extends an effective technological start-up. Thus, in this study, a fast start-up of the anammox process supported with an anammox-rich inoculum was performed in a sequencing batch reactor (SBR). Using anammox inoculation of SBR laboratory system, the start-up can be fastened to 85 days with $84.5 \%$ of nitrogen removal efficacy. The spatial distribution of nitrogen removal bacteria analysed with fluorescent in situ hybridisation revealed that anammox and nitrifiers are located side by side in the flocs and the relative number of ammonia and nitrite oxidisers decreased after 85 days of the experiment.
\end{abstract}

Keywords Anammox start-up · Nitrogen removal bacteria dynamics $\cdot$ Real Time PCR $\cdot$ FISH $\cdot$ TEM

\section{Introduction}

Despite intensive research in the field of nitrogen removal using nitrification-denitrification from wastewater, there is still a need for the search of alternative, cheaper and more effective processes to remove this biogenic compound (Liu

Editorial responsibility: M. Abbaspour.

A. Ziembińska-Buczyńska

aleksandra.ziembinska-buczynska@polsl.pl

1 Environmental Biotechnology Department, Faculty of Power and Environmental Engineering, Silesian University of Technology, Akademicka 2 Str., 44-100 Gliwice, Poland

2 Faculty of Biology and Environmental Protection, Department of Animal Histology and Embryology, University of Silesia in Katowice, Bankowa 9 Str., 40-007 Katowice, Poland

3 Institute of Automatic Control, Faculty of Automatic Control, Electronics and Computer Science, Silesian University of Technology, Akademicka 16 Str., 44-100 Gliwice, Poland

4 Biotechnology Centre, Silesian University of Technology, Krzywoustego 8 Str., 44-100 Gliwice, Poland et al. 2016). Since last century, it is known that not only nitrifiers and denitrifiers take part in the nitrogen cycle, both in nature and in engineered systems. There is a group of bacteria performing autotrophic ammonium removal to gaseous nitrogen, widespread in anaerobic environments. These anammox (anaerobic ammonium oxidation) bacteria and their efficient performance are the basis of many new technologies in wastewater treatment developed since 1990s (García-Ruiz et al. 2018). There is no need for aeration and an extra carbon source dosage in the anammox process; thus, anammox-based technologies are cheaper than the traditional nitrification-denitrification combination. Despite obvious advantages, there are several disadvantages of the anammox process: anammox bacteria are relatively sensitive to drastic changes of technological parameters, such as $\mathrm{pH}$, temperature or free ammonia (Jin et al. 2012; Tomaszewski et al. 2017). Moreover, anammox bacteria grow slowly in comparison with other nitrogen removal bacteria [doubling time from 3.6 (Tsushima et al. 2007) to 18 days (Trigo et al. 2006)], which is the reason of the problems with a fast startup of the process in a technological scale, both at the beginning of the performance and after the operational problems 
causing the process efficacy failure. Usually, it takes from 100 to 390 days to start-up of anammox reactor (Tomaszewski et al. 2017); thus, fastening the start-up process would be advisable especially from the economic reasons. In situation of inoculating systems with the anammox biomass, the fast start-up problem can be overcome, but still there is no sufficient knowledge about the ecological relationships existing in such a community among various nitrogen removal bacterial groups (Liu et al. 2012).

It is widely known that biochemical processes being a part of the nitrogen biogeochemical cycle do not exist in nature separately. Also in artificial environments, such as wastewater treatment bioreactors, there is a large number of these processes linked together and the bacteria responsible for these biochemical reactions coexist in the complex community. The performance of nitrifiers, denitrifiers and anammox bacteria depends on technological parameters settled for the bioreactor. Thus, the studies at such community dynamics and relationships are crucial from the perspective of the fast reactor start-up, especially in a situation where a new bioreactor is inoculated with a mixture of the regular activated sludge and the anammox biomass.

In case of nitrogen removal systems, a wide range of physiochemical parameters can influence the community structure and bacterial ecological relationships in activated sludge. Among these parameters, substrates and oxygen concentration, temperature or inoculating microorganisms can play an important role (Liu et al. 2012; Third et al. 2005; van de Vossenberg et al. 2008). Information gained from the research on the dynamics of the nitrogen removal bacterial community performed during the start-up of the anammox system can be of the utmost importance for future fast start-ups and for maintaining the effective bioreactor performance.

In this study the relationships among nitrifiers, denitrifiers and anammox bacteria were monitored for 85 days of the sequencing batch reactor (SBR) start-up. The reactor was inoculated with activated sludge with the dominance of anammox bacteria to accelerate the start-up process to check faster start-up possibility and to present the microbial community relationships in a newly created environment. In order to present an insight into the bacterial community dynamics and to describe how particular nitrogen removal bacteria behave in new environment, fluorescent in situ hybridisation (FISH) and Real Time PCR analysis were used. The presence of anammox bacteria, whose intracellular structure differs from the regular bacterial cell by possessing a membrane structure known as anammoxosome, was confirmed by the transmission electron microscopy (TEM).

\section{Materials and methods}

\section{Experimental settings, physiochemical analysis and activated sludge sampling}

A 20L sequencing batch reactor inoculated with activated sludge from a municipal wastewater treatment plant and anammox sludge (1:1) was operated at the temperature of $32 \pm 3{ }^{\circ} \mathrm{C}$ (mean $\pm \mathrm{SD}$, standard deviation) with $\mathrm{pH}$ $7.8 \pm 0.3($ mean $\pm \mathrm{SD})$. The dissolved oxygen (DO) was below $0.1 \mathrm{mg} \mathrm{L}^{-1}$, and volatile suspended solids (VSS) was $1.6 \pm 0.4 \mathrm{~g} \mathrm{~L}^{-1}$ (mean $\pm \mathrm{SD}$ ). The reactor was fed with a mineral medium adapted from van de Graaf et al. (1996). The total nitrogen loading rate (NLR) was regulated by the addition of $\mathrm{NH}_{4} \mathrm{Cl}$ and $\mathrm{NaNO}_{2}$, while other elements were dosed in constant concentrations: $0.048 \mathrm{~g} \mathrm{KHCO}_{3} \mathrm{~L}^{-1}$, $0.041 \mathrm{~g} \mathrm{KH}_{2} \mathrm{PO}_{4} \mathrm{~L}^{-1}, 0.228 \mathrm{~g} \mathrm{MgSO}_{4} \cdot 7 \mathrm{H}_{2} \mathrm{O} \mathrm{L}^{-1}$, $0.007 \mathrm{~g} \mathrm{FeSO}_{4} \cdot 7 \mathrm{H}_{2} \mathrm{O} \mathrm{L}^{-1}$ and $0.004 \mathrm{~g} \mathrm{EDTA} \mathrm{L}^{-1}$. $\mathrm{pH}$ was corrected using $10 \% \mathrm{HCl}$ or $10 \% \mathrm{NaOH}$.

Regular measurements of ammonium, nitrite and nitrate nitrogen were conducted using fast photometric tests (MERCK Millipore) with a photometer (MERCK Spectroquant ${ }^{\circledR}$ NOVA60). Temperature and $\mathrm{pH}$ were monitored by JUMO tecLine HD- the $\mathrm{pH}$ combination electrode. The DO concentration was measured by ELMETRON Conductivity/Oxygen Meter CCO-505 with the ELMETRON COG-1 oxygen sensor. Concentrations of VSS were measured according to the standard method (APHA 2005).

Activated sludge samples were collected at 2-week intervals to $50 \mathrm{~mL}$ sterile Falcon flasks and frozen at $-20^{\circ} \mathrm{C}$ until further procedure.

\section{DNA isolation}

The activated sludge samples were washed thrice with $1 \times$ PBS to remove potential PCR inhibitors. Total bacterial DNA was isolated with a mechanical method. The samples $(0.2 \mathrm{~g})$ were suspended in $1 \mathrm{~mL}$ of the extraction buffer (100 mM Tris-HCl, $100 \mathrm{mM}$ EDTA, $1.5 \mathrm{M} \mathrm{NaCl}$, $\mathrm{pH}=8.0$ ), and then, a mixture of bead beating glass pearls, in sizes: $1.25-1.55 \mathrm{~mm}$ and $0.4-0.6 \mathrm{~mm}$ (Roth, Germany) was added. The mixture was shaken intensively with a vortex and mixed horizontally for $20 \mathrm{~min}$ at $1400 \mathrm{rpm}$ using a thermomixer (Eppendorf). In the next step $200 \mu \mathrm{L}$ of $10 \%$ SDS (Sigma) was added to the samples, which were incubated with $1400 \mathrm{rpm}$ mixing at $65^{\circ} \mathrm{C}$ for $30 \mathrm{~min}$. The samples were centrifuged twice (10 min, 13,000 rpm), and the $500 \mu \mathrm{L}$ of supernatant was placed at silica columns (A\&A Biotechnology). The columns were washed twice with the A1 buffer (A\&A Biotechnology), and DNA was eluted from the column with $30 \mu \mathrm{L}$ of MilliQ water. DNA concentration 
was measured with a Qubit Fluorometer (Invitrogen) and kept frozen at $-20^{\circ} \mathrm{C}$ for further analysis.

\section{Transmission electron microscopy}

The activated sludge samples from inoculum were fixed with $2.5 \%$ glutaraldehyde buffered with $0.1 \mathrm{M}$ phosphate buffer (pH 7.4) (5 day at $4{ }^{\circ} \mathrm{C}$ ) and postfixed with $1 \% \mathrm{OsO}_{4}$ in a $0.1 \mathrm{M}$ phosphate buffer (30 min at room temperature). After dehydration in increasing concentrations of ethanol $(30,50$, $70,90,95$, and $100 \%$, each for $5 \mathrm{~min}$ ), a mixture of $100 \%$ ethanol and acetone (1:1, $5 \mathrm{~min})$, and acetone $(2 \times 5 \mathrm{~min})$, the material was embedded in the epoxy resin (Epoxy Embedding Medium Kit, Sigma). Ultrathin sections were cut on a Leica ultracut UCT25 ultramicrotome. Ultrathin sections (50 nm thick), mounted on the formvar-covered grids (50 mesh), were stained with uranyl acetate and lead citrate (Reynolds 1963) and examined with a transmission electron microscope (Hitachi H500 at $75 \mathrm{kV}$ ).

\section{Fluorescent in situ hybridisation (FISH)}

In order to estimate the amount and identify the active part of the bacterial community, fluorescent in situ hybridisation was used. The biomass samples were fixed by adding three volumes of the $4 \%(\mathrm{w} / \mathrm{v})$ paraformaldehyde solution and incubated for $3 \mathrm{~h}$ in $4{ }^{\circ} \mathrm{C}$. Then, the samples were washed thrice with phosphate-buffered saline $(1 \times \mathrm{PBS}, \mathrm{pH}=7.5)$ and resuspended in a 1:1 mixture of phosphate-buffered saline and absolute ethanol. Fixed samples were stored at $-20{ }^{\circ} \mathrm{C}$ for the further analysis. Selected probes which hybridise with the $16 \mathrm{~S}$ rRNA have been used to collect data on the nitrogen removal bacteria community in samples collected from the bioreactor (Table 1). All oligonucleotide probes were obtained from Bionovo, Poland.

For fluorescent in situ hybridisation, $10 \mu \mathrm{L}$ of a fixed sample was applied on a well of glass slide (Thermo Scientific), dried and sequentially dehydrated in solutions of $50 \%, 80 \%$ and $97 \%$ ethanol (v/v) in PBS for 3 min each. To start hybridisation, $10 \mu \mathrm{L}$ of hybridisation buffer (containing the appropriate formamide concentration for each probe, Table 1) and $1 \mu \mathrm{L}$ of fluorescently labelled specific probes and $1 \mu \mathrm{L}$ of the EUB probe targeting most of bacteria (at a concentration of $5 \mathrm{pmol} / \mu \mathrm{L}$ for $\mathrm{Cy} 3$ and $8.3 \mathrm{pmol} / \mu \mathrm{L}$ for FLUOS) were added to the well. The hybridisation was conducted for $90 \mathrm{~min}$ at $46{ }^{\circ} \mathrm{C}$ in a humidified chamber. Following hybridisation, a stringent washing step was performed for $15 \mathrm{~min}$ at $48{ }^{\circ} \mathrm{C}$ in a buffer with the appropriate $\mathrm{NaCl}$ concentration (Table 1), $20 \mathrm{mM}$ Tris- $\mathrm{HCl}, \mathrm{pH}=7.0$, $5 \mathrm{mM}$ EDTA and $0.01 \%$ SDS. FISH signal was evaluated after adding the mounting agent-Citifluor (Citifluor, London, UK). The signal obtained from specific probes for the nitrogen removal bacteria community was compared with the signal obtained from the EUBMIX probe targeting most of the bacteria. In order to estimate the number of individual nitrogen removal bacterial groups on the 3rd and 85th day of the experiment, the measurements were performed in at least 20 replicates for each group. Statistical analyses

Table 1 Details of the fluorescent in situ hybridisation (FISH) probes' procedure used in the experiment

\begin{tabular}{|c|c|c|c|c|c|}
\hline Aim & Probe & Sequence $\left(5^{\prime}-3^{\prime}\right)$ & $\begin{array}{l}\text { Formamide } \\
\text { concentration } \\
(\%)\end{array}$ & $\begin{array}{l}5 \mathrm{M} \mathrm{NaCl} \\
\text { concentration } \\
(\mu \mathrm{L})\end{array}$ & References \\
\hline All bacteria & $\begin{array}{l}\text { EUB MIX (EUB } \\
338+\text { EUB } 338 \\
\text { II + EUB } 338 \text { III) }\end{array}$ & $\begin{array}{l}\text { GCT GCC TCC CGT AGG } \\
\text { AGT + GCA GCC ACC } \\
\text { CGT AGG TGT + GCT } \\
\text { GCC ACC CGT AGG } \\
\text { TGT }\end{array}$ & $0-50$ & 100-9000 & Amann et al. (1990) \\
\hline All known Planctomycetes & Pla 46f & $\begin{array}{l}\text { GAC TTG CAT GCC TAA } \\
\text { TCC }\end{array}$ & 30 & 1020 & Neef et al. (1998) \\
\hline \multirow[t]{2}{*}{ Anammox bacteria } & Amx 368 & $\begin{array}{l}\text { CCT TTC GGG CAT TGC } \\
\text { GAA }\end{array}$ & 15 & 3180 & van der Star et al. (2008) \\
\hline & Amx 820 & $\begin{array}{l}\text { AAA ACC CCT CTA CTT } \\
\text { AGT GCC C }\end{array}$ & 40 & 460 & Schmid et al. (2000) \\
\hline \multirow[t]{2}{*}{$\begin{array}{l}\text { Betaproteobacterial ammo- } \\
\text { nia-oxidising bacteria }\end{array}$} & Nso190 & $\begin{array}{l}\text { CGA TCC CCT GCT TTT } \\
\text { CTC C }\end{array}$ & 55 & 100 & Mobarry et al. (1996) \\
\hline & Nso1225 & $\begin{array}{l}\text { CGC CAT TGT ATT ACG } \\
\text { TGT GA }\end{array}$ & 35 & 700 & \\
\hline NOB (Phylum Nitrospirae) & Ntspa 712 & $\begin{array}{l}\text { CGC CTT CGC CAC CGG } \\
\text { CCT TCC }\end{array}$ & 50 & 180 & Daims et al. (2001) \\
\hline \multirow[t]{2}{*}{ Potential denitrifiers } & Pae 997 & GCT GGC CTA GCC TTC & 0 & 9000 & Crocetti et al. (2000) \\
\hline & PAR 651 & $\begin{array}{l}\text { ACC TCT CTC GAA CTC } \\
\text { CAG }\end{array}$ & 40 & 460 & Neef et al. (1998) \\
\hline
\end{tabular}


of the obtained data were performed with Statistica 12.0 Software (StatSoft). Shapiro-Wilk test was used to test the data normality, and then, based on the statistic results, the Mann-Whitney $U$ test was used to examine the significance of the differences between the results obtained from 3rd and 85th day of the experiment; $p$ values $<0.05$ were considered statistically significant.

\section{Real Time PCR}

On the basis of total bacterial DNA isolated from the activated sludge samples, Real Time PCR for functional genes for $\mathrm{AOB}, \mathrm{NOB}$, anammox and denitrifiers was performed using Real Time PCR 2xRT PCR Mix SYBR A (A\&A Biotechnology). Five ng of the DNA templates was used in the total reaction volume of $20 \mu \mathrm{L}$. The reaction was lead in Stratagene Mx3005P Thermocycler (Agilent Technologies) in the SYBR Green system in triplicates. The Real Time PCR was performed using primers presented in Table 2 according to the procedure described previously for each primer set (Ferris et al. 1996; Li et al. 2012b; Gerbl et al. 2014; Kim et al. 2011). Relative quantification of functional genes was calculated in relation to the $16 \mathrm{~S}$ rRNA reference gene representing the total bacterial community and presented as a mean value of triplicated data set. The values were calculated by the use of formula $2^{\Delta C_{t}}$, where $\Delta c_{t}=C_{t_{\text {ref }}}-C_{t_{\text {anal }}} \cdot C_{t_{\text {ref }}}$ is $C_{t}$ of reference gene (bacterial $16 \mathrm{~S}$ rRNA gene), while $C_{t}$ is $C_{t}$ value for analyzed gene.

\section{Results and discussion}

To present an insight into the newly created community of the activated sludge of SBR reactor, two molecular methods: FISH and Real Time PCR were used. These analyses were supported with physiochemical measurements during the total length of the experiment to present the effectiveness of the nitrogen removal. As it is presented in Fig. 1, ammonium, nitrite and nitrate concentrations were analysed.

The feeding strategy during the first 22 days was based on the increase in the NLR when the nitrogen removal efficiency was stable. NLR was gradually increased from 0.082 to $0.343 \mathrm{~kg} \mathrm{~N} \mathrm{~m}^{-3} \mathrm{day}^{-1}$. At same time, the nitrogen removal rate (NRR) increased from 0.061 to $0.326 \mathrm{~kg} \mathrm{~N} \mathrm{~m}^{-3}$ day $^{-1}$ on day 22. After this period, the reactor was operated with the average NLR $0.340 \pm 0.031 \mathrm{~kg} \mathrm{~N} \mathrm{~m}^{-3} \mathrm{day}^{-1}($ mean \pm SD) and NRR $0.310 \pm 0.030 \mathrm{~kg} \mathrm{~N} \mathrm{~m}^{-3} \mathrm{day}^{-1}($ mean $\pm \mathrm{SD}$ ). An almost complete nitrogen removal was demonstrated

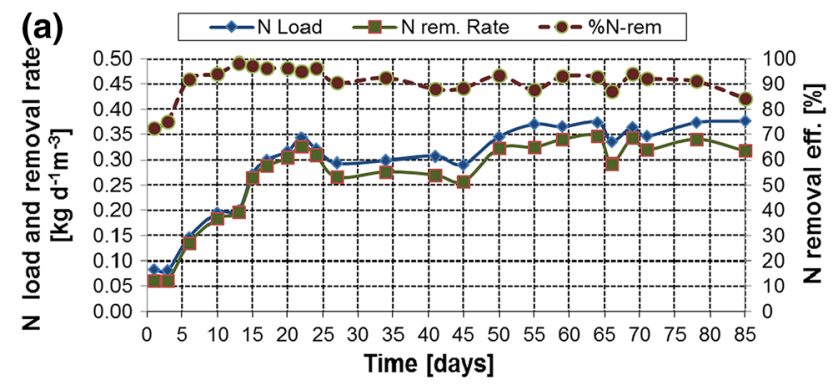

(b) $\rightarrow-\mathrm{N}-\mathrm{NH} 4$ in $\rightarrow-\mathrm{E}-\mathrm{N}-\mathrm{NO} 2$ in $\rightarrow-\mathrm{N}-\mathrm{NH} 4$ out $-\mathrm{e}-\mathrm{N}-\mathrm{NO} 2$ out $\rightarrow \bullet-\mathrm{N}-\mathrm{NO} 3$ out

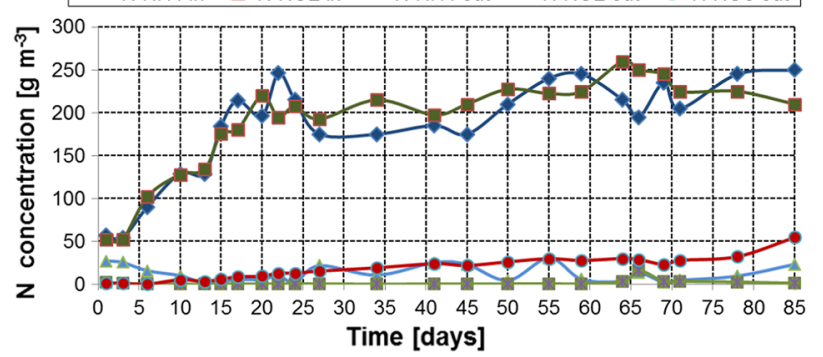

Fig. 1 Physiochemical performance of SBR reactor during 85 days of the experiment; a total nitrogen loads and their removal rates, $\mathbf{b}$ ammonia, nitrite and nitrate concentrations

Table 2 Primers used for Real Time PCR in this study

\begin{tabular}{|c|c|c|c|c|}
\hline Aim & Target gene & Primers & Sequence $5^{\prime}-3^{\prime}$ & Bibliography \\
\hline \multirow[t]{2}{*}{ Bacteria } & \multirow[t]{2}{*}{ 16S rRNA } & $1055 \mathrm{~F}$ & ATGGCTGTCGTCAGCT & \multirow[t]{2}{*}{ Ferris et al. (1996) } \\
\hline & & $1392 \mathrm{R}$ & ACGGGCGGTGTGTAC & \\
\hline \multirow[t]{2}{*}{ Ammonia oxidisers } & \multirow[t]{2}{*}{ Amo } & amoA-1-F & GGGGTTTCTACTGGTGGT & \multirow[t]{2}{*}{ Li et al. (2012b) } \\
\hline & & $\operatorname{amoA}-2 \mathrm{R}$ & CCCCTCKGSAAAGCCTTCTTC & \\
\hline \multirow[t]{2}{*}{ Nitrite oxidisers } & \multirow[t]{2}{*}{$N x r$} & nxrA-RT-F & GTG GTC ATG CGC GTT GAG CA & \multirow[t]{2}{*}{ Gerbl et al. (2014) } \\
\hline & & nxrA-RT-R & TCG GGA GCG CCA TCA TCC AT & \\
\hline \multirow[t]{2}{*}{ All known Planctomycetes } & \multirow[t]{2}{*}{$\mathrm{Hzo}$} & hzoCl1f1 & TGYAAGACYTGYCAYTGG & \multirow[t]{2}{*}{ Kim et al. (2011) } \\
\hline & & hzoCl1r2 & ACTCCAGATRTGCTGACC & \\
\hline \multirow[t]{4}{*}{ Denitrifiers } & \multirow[t]{2}{*}{ NirS } & $\operatorname{nirS} 1 \mathrm{f}$ & TACCACCCSGARCCGCGCGT & \\
\hline & & $\operatorname{nirS} 3 \mathrm{r}$ & GCCGCCGTCRTGVAGGAA & \\
\hline & \multirow[t]{2}{*}{ NirK } & nirK876 & ATYGGCGGVCAYGGCGA & \\
\hline & & nirK1040 & GCCTCGATCAGRTTRTGGTT & \\
\hline
\end{tabular}


between days 15 and $24(96.7 \pm 1.1 \%$, mean \pm SD), but it was probably improved by the endogenous denitrification, which is typical during the anammox process start-up ( $\mathrm{Li}$ et al. 2012a; Yu et al. 2013). However, after the 71 days of the experiment, the nitrate concentration in the effluent increased and the nitrogen removal efficiency dropped to $84.5 \%$ on day 85 , which can be an indicator of the end of a successful anammox process start-up (Li et al. 2012a; Yu et al. 2013).

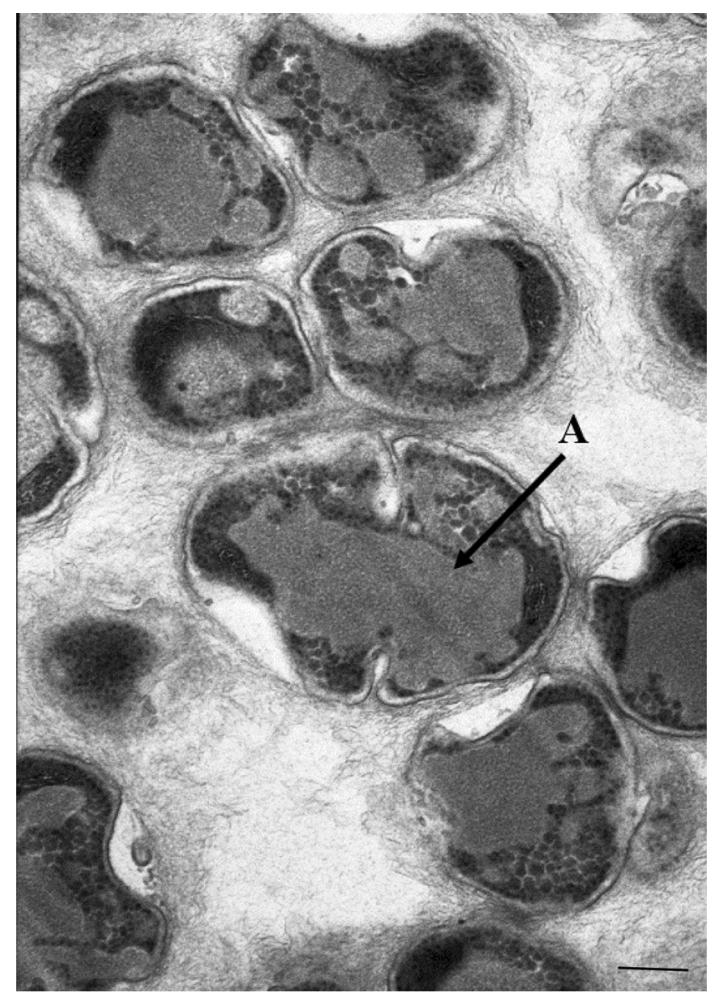

Fig. 2 Anammox bacteria cells in activated sludge samples visualised in transmission electron microscopy (TEM); A-anammoxosome. $\operatorname{Bar}=0.27 \mu \mathrm{m}$
From the beginning of the experiment, anammox bacteria were present in the bioreactor and it was possible to prepare transmission electron microscopy pictures of their cells (Fig. 2). The cell structure of anammox bacteria differs from the commonly known bacterial ultrastructure. Their cell possesses three independent compartments, known as the paryphoplasm, riboplasm and anammoxosome. The last one is a structure in which energy conservation occurs (van Teeseling et al. 2013). In case of this experiment, the anammoxosome was visible in a cross section of the anammox bacteria cell (indicated as A, Fig. 2).

Fluorescent in situ hybridisation (FISH) was used for this study in order to measure the abundance of particular bacterial groups as a per cent of the total bacterial community during the experiment. This analysis presents information about the active part of the community as the oligonucleotide probes target rRNA molecules in activated sludge. FISH enables also to present the spatial distribution of the particular bacterial groups in activated sludge flocs, which helps to explain the mutual relationships among nitrogen removal bacteria (Fig. 3).

The seeding activated sludge consisted of both floccular and granular sludge with the dominance of anammox bacteria. As it was assumed the granules of anammox bacteria seem to dominate in the flocs (granules) with NOB, they are localised outside the flocs (Fig. 3a). AOB are located outside the NOB (Fig. 3b), but the observation of anammox and AOB together (Fig. 3c) leads to the statement that these two groups were side by side in the flocs (granules). These results are comparable with these obtained by Liu et al. (2012) working on the CANON reactors, and Pynaert et al.'s (2003) analysis of the spatial distribution of bacteria in a one-stage rotating biological contactor. Such a close location of AOB and anammox was explained in two ways: anammox bacteria are protected by $\mathrm{AOB}$, which consume oxygen and produce nitrite, or AOB can perform some sort of anaerobic metabolism (Pynaert et al. 2003; Liu et al. 2012). We cannot also exclude the changes in the spatial
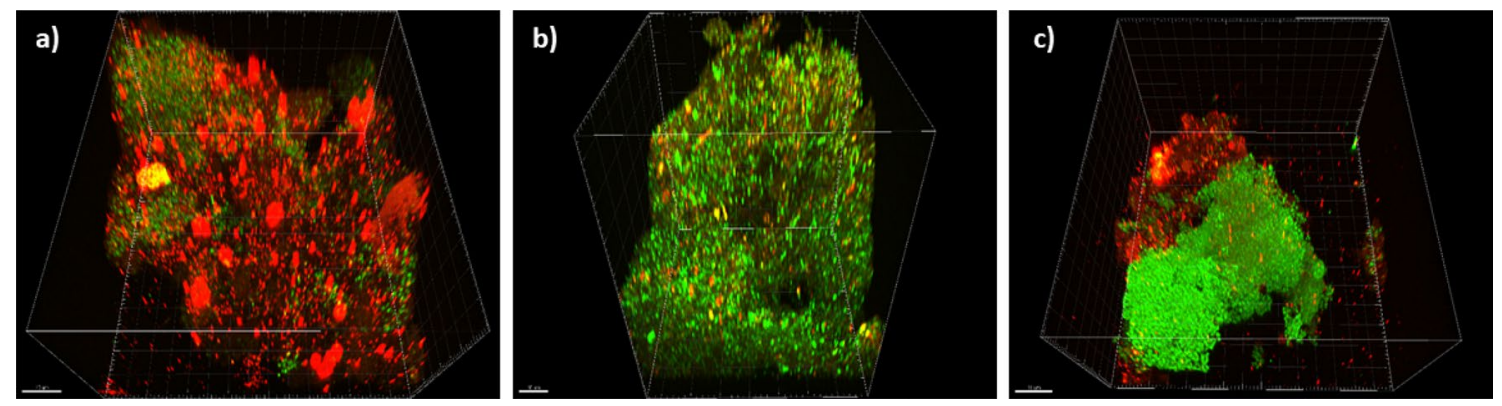

Fig. 3 Fluorescent in situ hybridisation on confocal microscope performed to present the spatial distribution of the particular nitrogen removal bacteria in activated sludge flocs using probes: a AMX820 for anammox bacteria in Cy3 (red) and Ntspa712 for NOB in FLUOS (green); b Ntspa712 for NOB in Cy3 (red) and Nso1225 for AOB in FLUOS (green); c MX820 for anammox bacteria in Cy3 (red) and Nso1225 for AOB in FLUOS (green) 
distribution of particular nitrogen removal groups during fixation and samples preparation as the samples from the beginning of the experiment were partially granular, but the technological parameters settled in SBR lead to disintegration of the granules into floccular sludge.

By calculating the ratio of the signal for specific probes for $\mathrm{AOB}, \mathrm{NOB}$ and potential denitrifiers to the signal obtained for most bacteria via the EUBMIX probe, a semiquantitative analysis of nitrogen removal bacteria groups was conducted (Fig. 4). As it had been suspected, the relative number of AOB and NOB decreased after 85 days of the experiment from $18.4 \%$ to $15.5 \%$ and $21.02 \%$ to $14 \%$ of the total bacterial community, respectively. It is important to mention that activated sludge samples are highly heterogeneous. In case of this analysis, the heterogeneity of the samples was even higher due to the fact that the seeding sludge was derived from two different technological systems: a full-scale wastewater treatment plant (floccular sludge), and a nitritation-anammox laboratory-scale fixed bed reactor (granular sludge; partially disintegrated during the bioreactor operation). That is why the analysis using FISH was performed in at least twenty repetitions per analysis, but still the statistical analysis performed on these samples points at high diversity of the samples composition. The proportion of anammox bacteria as well as denitrifiers also slightly decreased, but these results can be explained by the change in the reactor volume and the adaptation phase of the community.

During the start-up in the SBR, microorganisms needed to adapt to a smaller volume of the reactor as well as to the newly created ecosystem. As it can be seen by comparing these results to the physiochemical analysis, the decrease in the number of active bacteria did not influence negatively the reactor performance. This result stands along with the results obtained by Liu et al. (2012). In their work there was also no direct relationship between the performance of the reactor and the quantity of individual bacterial groups.

Interestingly, the number of bacterial functional genes analysed with the Real Time PCR decreased only in case of NOB; for AOB it was kept at a similar level (Table 3). Also the number of AOB detected with Real Time PCR in comparison with other nitrogen removal bacteria is the lowest. This analysis was performed at DNA level; thus, it is impossible to state that at least part of AOB community was active. An explanation for such a situation could be that SBR during the start-up of the anammox process was kept anoxic to create an anammox-friendly environment and the anoxic conditions caused that AOB remained inactive. Also a previous study (Hellinga et al. 1998; Liu et al. 2012) stated that the maximum specific growth of ammonia oxidisers is higher than that of nitrite oxidisers in temperatures over $25^{\circ} \mathrm{C}$, as well as in lower dissolved oxygen concentrations (De Clippeleir et al. 2011); thus, in this experiment, with temperature of $32 \pm 3{ }^{\circ} \mathrm{C}$ (mean $\pm \mathrm{SD}$ ) and DO below $0.1 \mathrm{mg} \mathrm{L}^{-1} \mathrm{AOB}$ and anammox could outcompete NOB. These results stay along with the results from FISH, and it is highly probable that the process settings caused partial elimination of NOB from the system.

The anammox bacteria number calculated as the $\mathrm{Hzo}$ gene activity per one copy of 16S rRNA gene increased during the experiment from 3.07 to $3.64 \times 10^{-1}$. These results are in line with the physiochemical data, according
Fig. 4 Comparison of the relative abundance of individual nitrogen removal bacterial groups on the $3 \mathrm{rd}$ and 85 th day of the experiment analysed using fluorescent in situ hybridisation (FISH). Abundancy of the bacterial group was estimated as a comparison of the signal for specific probes for anammox bacteria, AOB, NOB and potential denitrifiers to the signal obtained for most bacteria via the EUBMIX probe

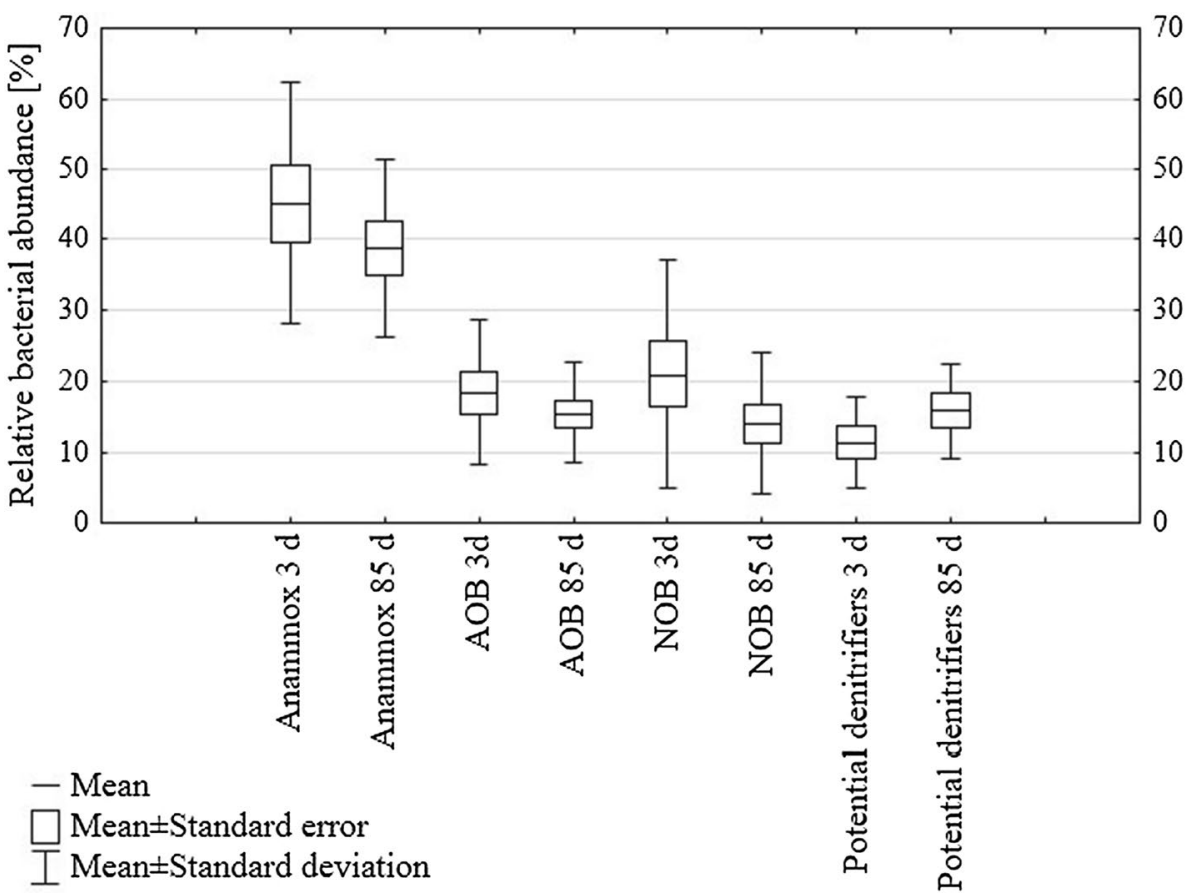


Table 3 Relative quantification of functional genes for AOB, NOB, anammox and denitrifiers in the activated sludge samples obtained with Real Time PCR

\begin{tabular}{|c|c|c|c|c|c|}
\hline \multirow{2}{*}{$\begin{array}{l}\text { Day of the } \\
\text { experiment }\end{array}$} & \multicolumn{5}{|c|}{ Relative quantification of functional genes per one copy of $16 \mathrm{~S}$ rRNA gene } \\
\hline & AmoA & NxrA & $\mathrm{Hzo}$ & $\operatorname{nir} S$ & $\operatorname{nirK}$ \\
\hline $3 \mathrm{rd}$ & $6.14 \times 10^{-6}$ & $7.63 \times 10^{-4}$ & $3.07 \times 10^{-1}$ & $4.74 \times 10^{-2}$ & $4.82 \times 10^{-2}$ \\
\hline 85 th & $6.55 \times 10^{-6}$ & $5.87 \times 10^{-4}$ & $3.64 \times 10^{-1}$ & $5.04 \times 10^{-2}$ & $4.70 \times 10^{-2}$ \\
\hline
\end{tabular}

The values present a mean value from a triplicate analysis and were calculated as copy number of the target genes per one copy 16S rRNA reference gene to which the anammox process was introduced and worked effectively (Fig. 1). The relative abundance of the anammox bacteria presented as FISH results decreased from 45.14 to $38.68 \%$. However, this difference in the anammox bacteria abundancy is not statistically significant $(p=0.35)$, and it should be emphasised that the samples were highly heterogeneous, which hindered the analysis. As it could be suspected, the anammox bacteria group used as a seeding sludge was relatively abundant in the inoculum (Fig. 4) and the relative number of the $\mathrm{Hzo}$ gene is much higher from the beginning of the experiment than the functional genes of the other nitrogen removal bacteria (Table 3 ). The inoculum derived from both the communal wastewater treatment plant (WWTP) and the lab-scale anammox reactor, thus in these environments a large number of ecological niches were potentially available. When directed to a laboratory-scale bioreactor, although with optimal anammox parameters, the number of ecological niches decreased drastically and the number of the anammox bacteria dropped.

The results of FISH and Real Time PCR for denitrifiers seem to be convergent. Although the average relative abundance of this bacterial group increased from 11.41 to $16 \%$, as in case of anammox bacteria, this difference is not statistically significant $(p=0.19)$. Both abundancy of denitrifies during the reactor start-up and the NirS and NirK gene number indicate that the activity of these bacteria remains relatively constant.

It could be suspected that as in case of the anammox bacteria, the new environment caused a sort of specialisation due to the lower niche number, and their number decreased slightly but the activity visible as physiochemical analysis was high. Interestingly, the number of denitrifiers remains at a similar level at the beginning and the end of the startup of the process, which emphasises the possibility of the presence of endogenous denitrification, which was supported with physiochemical data (Fig. 1). These results support the thesis that nitrogen removal bacteria coexist in wastewater treatment systems and are linked with physiological and ecological relationships highly dependent on technological parameters which are responsible for their dominance. Studies on the dynamics of particular groups during technological processes could be helpful in optimising the process to reach high efficacy.

\section{Conclusion}

The anammox-rich inoculum enables to shorten the start-up of the anammox process to 85 days, when bioreactor reached the level of $84.5 \%$ nitrogen removal efficacy.

According to the FISH results, it could be stated that particular nitrogen removal bacteria stay in a close relationship with each other and they cooperate in the community performing a particular nitrogen removal process which is the most suitable under the actual technological parameters. The obtained results support the thesis that AOB and anammox bacteria coexist in a close relationship in WWTPs system and $\mathrm{AOB}$ protective role is possible.

The number of anammox bacteria increased slightly during the experiment, but their performance was at a high level which let us to suspect that the bioreactor size caused microbial specialisation for lower ecological niche number. Nonetheless, the other nitrogen removal bacteria are still present in the system, and probably, a smaller bioreactor volume can still serve as a reservoir of ecological microniches suitable for them.

The studies on the dynamics of particular groups during technological processes could be helpful in optimising the process to reach its high efficacy and a faster bioreactor start-up.

Acknowledgments This research was financed by Polish National Science Centre, Grant No: UMO-2013/09/D/NZ9/02438 and supported by Silesian University of Technology Grant No: 08/080/BK_18/0054. Authors would like to thank Anna Długołęcka for Real Time PCR analysis support.

Open Access This article is distributed under the terms of the Creative Commons Attribution 4.0 International License (http://creativeco mmons.org/licenses/by/4.0/), which permits unrestricted use, distribution, and reproduction in any medium, provided you give appropriate credit to the original author(s) and the source, provide a link to the Creative Commons license, and indicate if changes were made.

\section{References}

Amann RI, Binder BJ, Olson RJ, Chisholm SW, Devereux R, Stahl DA (1990) Combination of 16S rRNA-targeted oligonucleotide probes with flow cytometry for analyzing mixed microbial populations. Appl Environ Microbiol 56:1919-1925 
APHA (2005) Standard methods for the examination of water and wastewater, 20th edn. American Water Works Association (AWWA) \& Wat. Env. Fed. (WEF), Washington

Crocetti GR, Hugenholtz P, Bond PL, Schuler A, Keller J, Jenkins D, Blackall LL (2000) Identification of polyphosphate-accumulating organisms and design of 16S rRNA-directed probes for their detection and quantitation. Appl Environ Microbiol 66:1175-1182

Daims H, Nielsen JL, Nielsen PH, Schleifer KH, Wagner M (2001) In situ characterization of Nitrospira-like nitrite-oxidizing bacteria active in wastewater treatment plants. Appl Environ Microbiol 67:5273-5284

De Clippeleir H, Yan X, Verstraete W, Vlaeminck SE (2011) Oland is feasible to treat sewage-like nitrogen concentrations at low hydraulic residence time. Commun Agric Appl Biol Sci 76:163-166

Ferris MJ, Muyzer G, Ward DM (1996) Denaturing gradient gel electrophoresis profiles of $16 \mathrm{~S}$ rRNA-defined populations inhabiting a hot spring microbial mat community. Appl Environ Microbiol 62:340-346

García-Ruiz MJ, Maza-Márquez P, González-López J, Osorio F (2018) Nitrogen removal capacity and bacterial community dynamics of a Canon biofilter system at different organic matter concentrations. Chemosphere 193:591-601. https://doi.org/10.1016/j.chemospher e.2017.11.066

Gerbl F, Weidler GW, Wanek W, Erhard A, Stan-Lotter H (2014) Thaumarchaeal ammonium oxidation and evidence for a nitrogen cycle in a subsurface radioactive thermal spring in the Austrian Central Alps. Front Microbiol 5:1-17. https://doi.org/10.3389/fmicb .2014.00225

Hellinga C, Schellen AAJC, Mulder JW, van Loosdrecht MCM, Heijnen JJ (1998) The SHARON process: an innovative method for nitrogen removal from ammonium-rich waste water. Water Sci Technol 37:135-142

Jin R-C, Yang G-F, Yu J-J, Zheng P (2012) The inhibition of the anammox process: a review. Chem Eng J 197:67-79

Kim YM, Lee DS, Park C, Park D, Park JM (2011) Effects of free cyanide on microbial communities and biological carbon and nitrogen removal performance in the industrial sludge process. Water Res 45:1267-1279

Li H, Zhou S, Ma W, Huang G, Xu B (2012a) Fast start-up of ANAMMOX reactor: operational strategy and some characteristics as indicators of reactor performance. 2012. Desalination 286:436-441

Li XR, Xiao YP, Ren WW, Liu ZF, Shi JH, Quan ZX (2012b) Abundance and composition of ammonia-oxidizing bacteria and archaea in different types of soil in the Yangtze River estuary. J Zhejiang Univ Sci B 13:769-782

Liu T, Li D, Zeng H, Li X, Liang Y, Chang X, Zhang J (2012) Distribution and genetic diversity of functional microorganisms in different CANON reactors. Bioresour Technol 123:574-580. https:// doi.org/10.1016/j.biortech.2012.07.114 Epub 2012 Aug 7

Liu T, Li D, Zhang J, Lv Y, Quan X (2016) Effect of temperature on functional bacterial abundance and community structure in CANON process. Biochem Eng J 105:306-313
Mobarry BK, Wagner M, Urbain V, Rittmann BE, Stahl DA (1996) Phylogenetic probes for analyzing abundance and spatial organization of nitrifying bacteria. Appl Environ Microbiol 62:2156-2162

Neef A, Amann R, Schlesner H, Schleifer KH (1998) Monitoring a widespread bacterial group: in situ detection of planctomycetes with 16S rRNA-targeted probes. Microbiology 144:3257-3266

Pynaert K, Smets BF, Wyffelts S, Beheydr D, Siciliano SD, Verstraete W (2003) Characterization of an autotrophic nitrogen-removing biofilm from a highly loaded lab-scale rotating biological contractor. Appl Enivron Microbiol 69:3626-3635

Reynolds ES (1963) The use of lead citrate at high $\mathrm{pH}$ as an electronopaque stain in electron microscopy. J Cell Biol 17:208-212

Schmid M, Twachtmann U, Klein M, Strous M, Juretschko S, Jetten MSM, Metzger JW, Schleifer KH, Wagner M (2000) Molecular evidence for genus level diversity of bacteria capable of catalyzing anaerobic ammonium oxidation. Syst Appl Microbiol 23:93-106

Third KA, Paxman J, Schmid M, Strous M, Jetten MS, Cord-Ruwisch $R$ (2005) Treatment of nitrogen-rich wastewater using partial nitrification and anammox in the CANON process. Water Sci Technol 52:47-54

Tomaszewski M, Cema G, Ziembińska-Buczyńska A (2017) Influence of temperature and $\mathrm{pH}$ on the anammox process: a review and meta-analysis. Chemosphere 182:203-214

Trigo C, Campos JL, Garrido JM, Mendez R (2006) Start-up of the Anammox process in a membrane bioreactor. J Biotechnol 126:475-487

Tsushima I, Kindaichi T, Okabe S (2007) Quantification of anaerobic ammonium-oxidizing bacteria in enrichment cultures by Real Time PCR. Wat Research 41:785-794

Van de Graaf AA, de Bruijn P, Robertson LA, Jetten MSM, Kuenen JG (1996) Autotrophic growth of anaerobic ammonium-oxidizing microorganisms in a fluidized bed reactor. Microbiology 142:2187-2196

van de Vossenberg J, Rattray JE, Geerts W, Kartal B, van Niftrik L, van Donselaar EG, Sinninghe Damsté JS, Strous M, Jetten MS (2008) Enrichment and characterization of marine anammox bacteria associated with global nitrogen gas production. Environ Microbiol 10:3120-3129. https://doi.org/10.1111/j.1462-2920.2008.01643 .x (Epub 2008 May 6)

van der Star WRL, Miclea AI, van Dongen UGJM, Muyzer G, Picioreanu C, van Loosdrecht MCM (2008) The membrane bioreactor: a novel tool to grow anammox bacteria as free cells. Biotechnol Bioeng 101:286-294

van Teeseling MC, Neumann S, van Niftrik L (2013) The anammoxosome organelle is crucial for the energy metabolism of anaerobic ammonium oxidizing bacteria. J Mol Microbiol Biotechnol 23:104-117. https://doi.org/10.1159/000346547

Yu Y-C, Gao D-W, Tao Y (2013) Anammox start-up in sequencing batch biofilm reactors using different inoculating sludge. Appl Microbiol Biotechnol 97:6057-6064 